\title{
«TIME PREFERENCE AND INVESTMENT EXPENDITURE»: COMMENT ON HÜLSMANN
}

\author{
XAVIER MÉRA*
}

Resumen: Hülsmann (2008) argumenta que pasar por alto los cambios en la preferencia temporal del lado de la demanda en el mercado de tiempo hace incompleto el análisis de Rothbard (1993) al representar indebidamente un incremento en el volumen de inversión como contrapartida necesaria a una caída en la tasa de interés pura. Centrándose en los determinantes de la demanda para bienes presentes, este paper muestra que, siendo las críticas de Hülsmann esencialmente válidas, Rothbard realmente explicó por qué el impacto directo de los cambios en la preferencia temporal debería reflejarse fundamentalmente en el lado de la oferta. Sin embargo, las implicaciones derivadas de ello fueron ignoradas por Hülsmann y Rothbard. Las exploraremos, demostrando que la curva de demanda presente y el volumen de inversión deberían considerarse esencialmente independientes de las preferencias temporales presentes, estando determinadas realmente por decisiones productivas pasadas. Esta aproximación permite una comprensión más «dinámica» del mercado de tiempo y los procesos de crecimiento.

Palabras clave: Preferencia temporal, gasto de inversión, mercado del tiempo, estructura de la producción, tipo de interés, tipos de crecimiento, macroeconomía austriaca.

Clasificación JEL: B53, E22, E23, E43, O11, O16, O40.

Abstract: Hülsmann (2008) argues that the neglect of time preference changes on the demand side of the time market renders Rothbard's (1993) analysis incomplete in that it unduly portrays a rise in the volume of investment as a necessary counterpart to a fall in the pure interest rate. Focusing on the

* GRANEM (Université d'Angers). Xavier Méra is a Ph.D. candidate at the University of Angers, France. He would like to thank Guido Hülsmann and Matthew McCaffrey for their advice and comments as well as the Ludwig von Mises Institute for providing logistical support. Email: xavier.mera@etud.univ-angers.fr. 
determinants of the demand for present goods, this paper shows that though Hülsmann's strictures are essentially valid, Rothbard has actually explained why the direct impact of time preference changes should display themselves mostly on the supply side. However, the implications have been neglected both by Hülsmann and Rothbard. We explore these implications, demonstrating that the present demand schedule and the volume of investment should be considered as mostly independent from present time preferences and determined instead by past production decisions. We show how this approach allows for a more "dynamic» understanding of the time market and growth processes.

Key words: Time Preference, Investment Expenditure, Time Market, Structure of Production, Interest Rate, Growth Types, Austrian Macroeconomics.

JEL Classification: B53, E22, E23, E43, O11, O16, O40.

\section{I \\ INTRODUCTION: \\ THE ORTHODOX AUSTRIAN TAKE ON THE TIME MARKET AND HÜLSMANN'S CHALLENGE}

As noticed by Hülsmann (2008), Murray Rothbard's main passages on the time market in Man, Economy, and State simply assume that time preference changes display themselves only on the supply for present goods vs. future goods side. As a consequence, the relationship between the originary or pure interest rate, the volume of aggregate investment and the proportion of aggregate consumption vs. aggregate investment is straightforward, always the same and altogether determined by time preferences. This is the orthodox Austrian view as presented by Rothbard.

When time preferences fall (when people become less presentoriented), the supply schedule of present goods rises (it shifts from S1 to S2 in the figure below), the interest rate falls and the volume of investment rises, as well as the ratio of aggregate investment vs. aggregate consumption. It follows, or so it seems, that growth is a one dimensional phenomenon, the structure of production being always altered in the same way. The structure becomes lengthier and thinner as the consumption base shrinks 
and spending is reshuffled toward higher stages, including new stages (see the graph on the right in diagram 1 below), which in the end brings a higher overall physical productivity per capita.

Alternatively, if time preferences rise (when people become more present-oriented), the supply schedule of present goods falls (from S2 to S1 above), the interest rate rises and the volume of investment spending falls, as well as the ratio of investment vs. consumption. The structure of production becomes shorter and wider as consumption spending rises and expenses are reshuffled toward lower stages, cutting the highest ones, which at the end of the process translates into a lower overall physical productivity per capita.

However, once one envisages with Hülsmann that the demand side could as well be affected by a change in time preferences, several other configurations of the time market and scenarios of growth or depression become possible. ${ }^{1}$ The relationship between the interest rate and the volume of investment does not have to be the same in all cases. For example, a rise of time preferences

\section{DiAGRAM 1}

IMPACT OF A TIME PREFERENCES FALL IN THE TIME MARKET AND THE STRUCTURE OF PRODUCTION ACCORDING TO ROTHBARD

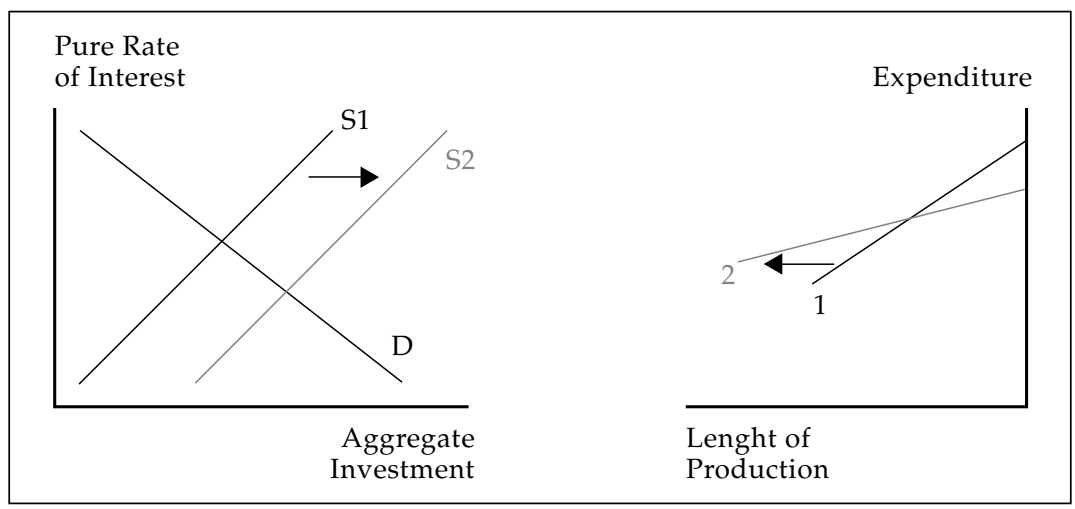

${ }^{1}$ See Hülsmann (2010) for the details of all scenarios. 
could display itself only on the demand side. This would imply that the demand for present goods would rise. The interest rate would then rise, as well as the volume of investment spending. Summarizing his strictures against Rothbard's view of the time market, Hülsmann (2008, p. 18) writes

The only necessary consequence of higher time-preference schedules is an increase of the price (of the pure interest rate). But there is no systematic impact on the volume of the market (aggregate savings exchanged for aggregate future goods). Depending on the (contingent) supply and demand schedules on the time market, the new equilibrium might involve a somewhat larger volume of aggregate saving, but it might just as well, and with equal likelihood, involve a somewhat reduced volume of aggregate saving.

Once one refuses to neglect the demand side, it also appears as a counterpart to the analysis of the time market that growth and depression become multidimensional phenomena. ${ }^{2}$

II HÜLSMANN'S NEGLECT OF A KEY ROTHBARDIAN
INSIGHT ON THE DEMAND FOR PRESENT GOODS:
A QUALIFIED DEFENSE OF ROTHBARD

There is a way to partially answer Hülsmann's challenge to Rothbard, based on some statements from Rothbard himself that Hülsmann overlooks. The fact is that Rothbard (1993, p. 405) did not entirely neglect the demand side of the time market. For him, time preference changes should mostly display themselves on the supply side.

It seems likely that the demand schedule for present goods by the original productive factors will be highly inelastic in response to changes

2 This should also affect business cycle theory since the usual Austrian narrative on this matter is dependent on the orthodox take on the time market and capital structure. 
in the interest rate. With the large base amount, the discounting by various rates of interest will very likely make little difference to the factor-owner. Large changes in the interest rate, which would make an enormous difference to capitalists and determine huge differences in interest income and the profitableness of various lengthy productive processes, would have a negligible effect on the earnings of the owners of the original productive factors [emphasis added].

Plus, as far as the other component of the demand schedule is concerned, the demand from capital goods owners, Rothbard (1993, p. 406) explains that:

It is true that capitalists, after investing in a stage of production, demand present goods in exchange for their product. This particular demand is inelastic in relation to interest changes since these capital goods also can have no subjective use-value for their producers. [emphasis added]

In the next section, Rothbard (1993, p. 419) adds:

We have seen that the productive demand for present goods tends to be inelastic with respect to interest rates; on the other hand, the consumers' loan curve will probably display greater elasticity. It follows that, on the demand side, changes in time preferences will display themselves mostly in the consumption demand schedule. On the supply side, of course, a rise in time preferences will lead to a shift of the SS curve to the left, with less being saved and invested at each rate of interest. [Emphasis added]

In other words, shifts of the supply curve will be far more sensitive to changes in time preferences than shifts of the demand curve. One can then expect that with a general change of time preferences in one direction, the effect on the supply schedule will be so strong relative to the effect on the demand schedule that Rothbard would be right after all on the relationship between the interest rate and the volume of investment. With a general lowering of time preferences, the shift or the supply schedule more than compensates for the shift of the demand schedule, the interest rate falls and the volume of investment rises. With a 
general rise in time preferences, the interest rate rises and the volume of investment falls.

It should be clear however that this rebuttal to Hülsmann would not be a general one. Under this line of reasoning, it is still possible-depending on whose preferences change- that the impact of lower time preferences for example would be a decline of investment. What the argument shows is only that such a scenario is less likely than what Hülsmann suggests. However, Rothbard's view still requires to be qualified by some set of empirical hypothesis.

III

ROTHBARD'S NEGLECT OF THE IMPLICATIONS
OF HIS OWN INSIGHT AND THE «NORMAL»
CONFIGURATION OF THE TIME MARKET

This partial solution to Hülsmann's challenge brings into light another issue with the Rothbardian take on the time market and the structure of production. For the strong Rothbardian relationship between interest and investment to hold, the demand schedule for present goods from factor owners must not only fail to fall when the supply schedule rises, it must also be elastic (as shown in diagram 1 above). Otherwise, however drastic a shift of the supply curve is, the volume of investment barely changes. But to the extent that the demand schedule of factor owners is elastic to the interest rate, it must also be sensitive to time preference changes, as Rothbard explains. Therefore, the demand schedule must have failed to fall, not because as a rule it can hardly fall but because people whose preferences change happen to be on the supply side only, a purely contingent condition. This implies in turn that the Rothbardian story is no more likely than other Hülsmannian scenarios. On the other hand, for the Hülsmannian alternative scenarios to be unlikely, the supply side of the time market must be far more sensitive to time preference changes than the demand from factor owners. But then again, if this demand schedule barely shifts when time preferences change, it should also be largely inelastic to interest, which means that the volume 
of investment barely changes when the interest rate rises or falls. Rothbard could not have it both ways.

Given that the demand for present goods by productive factor owners on the time market is likely to be «highly inelastic in response to changes in the interest rate» and that «on the demand side, changes in time preferences will display themselves mostly in the consumption demand schedule», as Rothbard explains, then it must follow that the volume of investment and the ratio of aggregate investment vs. aggregate consumption will be largely independent from time preferences and the interest rate. With a general lowering of time preferences, investment will only slightly rise (but could conceivably slightly fall) when the supply schedule of present goods will drastically rise and the demand schedule will slightly fall (see diagram 2 below).

Strictly speaking, as long as investment would slightly rise instead of slightly falling, this would of course still be compatible with the main results of Rothbard's take on the time market (the level of investment rises when the interest rate falls). However, this is not sufficient for Rothbard's strong relationship between interest and investment to hold. Moreover, this is not sufficient

\section{DiAGRAM 2}

IMPACT OF A TIME PREFERENCES FALL IN THE «NORMAL» TIME MARKET CONFIGURATION

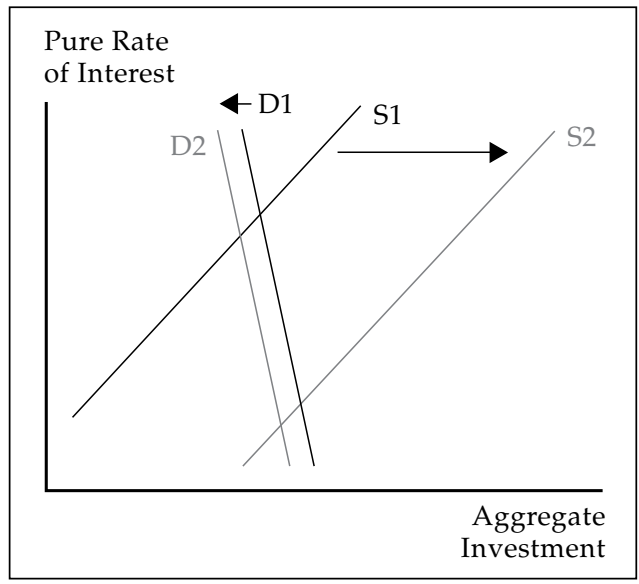


for Rothbard's growth scenario to hold as Hülsmann (2010) shows. If aggregate investment barely rises or stays the same, a falling interest rate means that the structure is only slightly thinner at its consumption base or as wide and that investment tends to be higher at each earlier stage than in the previous structure except at the highest stages which must be cut since they cannot be sustained without a higher volume of investment. This might entail an overall higher degree of roundaboutness and some kind of growth since some investment is reshuffled upward -despite the longest processes being shorter than previously- but this is hardly Rothbard's growth scenario. ${ }^{3}$

DIAGRAM 3

IMPACT OF A TIME PREFERENCES FALL IN THE «NORMAL» CONFIGURATION OF THE STRUCTURE OF PRODUCTION

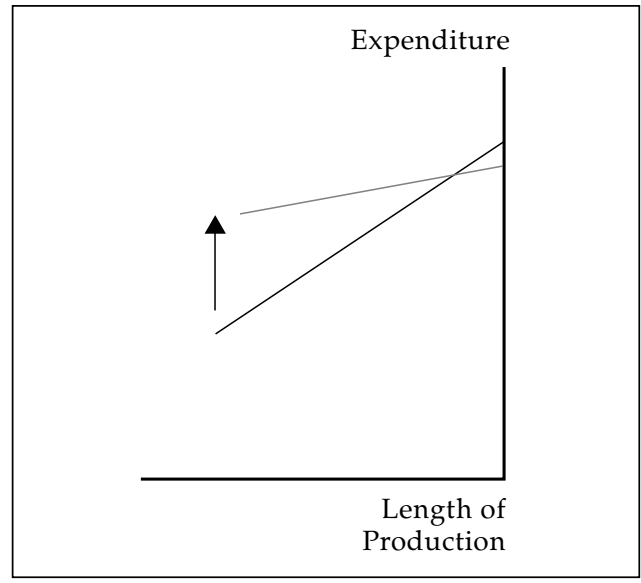

3 This would be similar to scenario n. 3 in Hülsmann (2010). 
IV

\section{AGGREGATE INVESTMENT IS LARGELY INDEPENDENT FROM TIME PREFERENCES}

It strikes us then that the correct position about the relationship between time preference, the interest rate and investment expenditure must combine Rothbard and Hülsmann's respective positions. Hülsmann is right, Rothbard does not provide us with a general explanation. Other scenarios than his are possible and a thorough analysis of the structure of production, growth and business cycle theory would have to take all the possible scenarios into account. On the other hand, contra Hülsmann, Rothbard is certainly right that the demand schedule for present goods by factor owners tends to be inelastic and less responsive to shifting time preference schedules than the supply schedule. Precisely because of this, one conclusion of Hülsmann's analysis is reinforced, namely that the volume of savings going into investment is largely independent of the interest rate. However, this result obtains not because the volume of investment could «with equal likelihood» rise or fall when time preferences and the interest rate fall (depending on the contingent factors of shifting demand and supply schedules) but in the sense that the demand for present goods of factor owners and the volume of investment are largely independent of time preferences.

That this is the case suggests that the emphasis on the determination of the volume of investment as the necessary simultaneous counterpart to the determination of the interest rate through time preferences becomes unjustified on Rothbard's own terms. It also suggests one should investigate the other determinants of the demand schedule and hence of the volume of investment. The essential task remaining is to investigate why this almost vertical demand for present goods is where it is and not somewhere else and what can make it really shift if not time preference changes. Getting back to Rothbard and the reasons why he claimed the demand schedule is likely to be inelastic to the interest rate and insensitive to time preference changes relative to the supply schedule will provide us with a starting point for this investigation. 


\section{$\mathrm{V}$ \\ TOWARD A MORE «DYNAMIC» THEORY OF THE TIME MARKET AND CAPITAL STRUCTURE}

The reason why the demand for present goods tends to be inelastic to interest is that it is the obverse side in the time market of the supplies of productive factors, supplies of future goods vs. present goods which tend to be inelastic to their prices. The reservation demand for land and capital goods will usually be negligible whatever their prices are, a fortiori whatever the time discount on their marginal productivity is. ${ }^{4}$ The reservation demand will be more important for labor because labor implies foregoing leisure, a consumption good (and also because there is the alternative of working for oneself, though Rothbard does not mention it in this context). However, changes in the interest rate will make only a small difference on wages relative to their importance for supplying present goods in the time market, hence the relative inelasticity of the supply of labor to the interest rate and its relative insensitivity to time preference changes on the part of laborers (Rothbard 1993, pp. 405-6).

Now, that the supplies of pieces of land, various types of labor and capital goods determine the position of the demand for present goods in the time market might seem to be a trivial insight but is nonetheless decisive and neglected as far as the determination of the volume of aggregate investment is concerned. For if the demand for present goods (the supply of productive factors) is likely to be inelastic to interest and relatively insensitive to time preference changes, the main causes of the volume of investment at any given time must be those that determine the supply of land, of labor and of capital goods at this time, apart from time preferences.

Investigating all the causes of the supplies for productive factors in details goes beyond the scope of this article but it must be stressed here that, except for the choice between work (for

\footnotetext{
${ }^{4}$ Specialists in some productive processes have usually no other use than sales for their products, so that they offer the stock whatever its price is, except insofar as they expect a higher future price.
} 
oneself or someone else) and leisure today, they are essentially the outcome of past valuations and decisions since the stock of land and capital goods as well as the size of the population at any point in time are the remnants of more or less remote past production decisions. In turn, these past causes do not only determine what the present volume of investment must be but co-determine with present time preferences what the interest rate will be in the immediate future since the interest rate is determined by the demand and the supply of present goods vs. future goods.

In particular, the supply of capital goods should be particularly responsive to previous production decisions and therefore to previous time preference schedules and availabilities of productive factors. A thorough analysis of the time market and growth scenarios should take this into account. In order to grasp the implications of this, let's assume what we considered above as the most probable scenario for growth is triggered at an arbitrary starting point in time.

At point $T$ in diagram 4 below, time preferences in the population suddenly become generally lower than before (at point T-1). The supply schedule for present goods rises from $S(T-1)$ to $S(T)$ while the relatively inelastic demand schedule slightly falls from $\mathrm{D}(\mathrm{T}-$ 1) to $D(T)$. The immediate outcome is a sharp fall in the interest rate and a slight rise in the volume of investment. In the structure of production (see diagram 5 below), the reallocation of funds has started. Capitalists tend to cut funding in the highest stages but put some more funds in the next highest than there were before. At T+1, additional supplies of capital goods produced in the highest remaining stages appear on the time market while the supply of capital goods at the previously highest stages is cut. The supply of capital goods at the lowest stages might initially diminish too as spending in these stages possibly falls under the pressure of a slightly lower consumption base. At $\mathrm{T}+2$, $\mathrm{T}+3$, etc. the effects of a higher level of roundaboutness are more and more felt as capitalists and laborers at lower stages start to use the recently built-at-the-previous- stages higher stock of capital goods. As time goes by, more and more additional capital goods are produced thanks to the improved physical productivity 
implied in the higher level of roundaboutness. However, this means that the demand for present goods rises as these goods enter the time market (in diagram 4 the demand curve shifts to the right each time additional goods are brought, with the chosen arbitrary stopping point of $\mathrm{T}+5$ ) while the supply schedule does not shift anymore. This in turn means that the volume of investment rises and the interest rate becomes higher again as illustrated below, with a crossing point between $S(T+5)$ - which is identical to $S(T)$ - and $D(T+5)$. This crossing point is above and at the right of the crossing point between $\mathrm{S}(\mathrm{T})$ and $\mathrm{D}(\mathrm{T})$.

DiAgRAM 4

SEQUENTIAL IMPACT ON THE TIME MARKET

OF A FALL IN TIME PREFERENCES

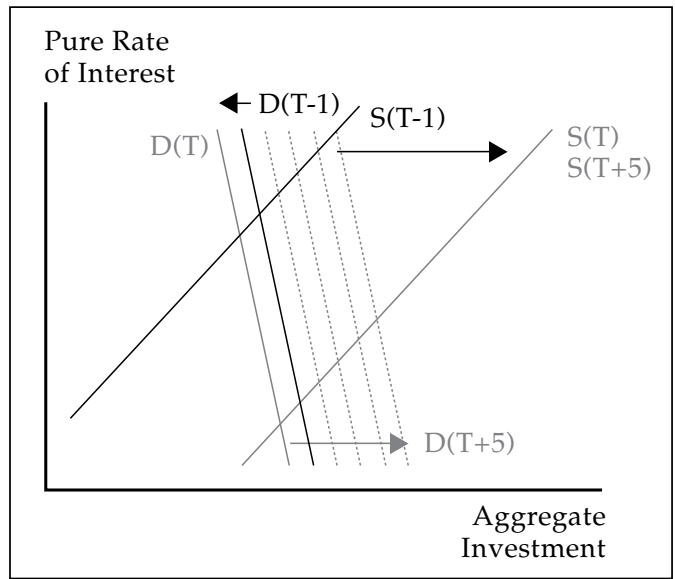

Given an initial demand for present goods, a change of time preferences triggers a sequence of events. Initially, it translates on the time market as a sharp fall in the interest rate with an almost unchanged level of aggregate investment. The corresponding growth mechanism is essentially a change in relative spending between stages, which is illustrated in diagram 5 above from a shift to line 1 to line $2 .{ }^{5}$ As soon as the physical effects of these

5 See Hülsmann (2010) for the different growth mechanisms. 


\section{Diagram 5}

\section{SEQUENTIAL IMPACT ON THE PRODUCTION STRUCTURE OF A FALL IN TIME PREFERENCES}

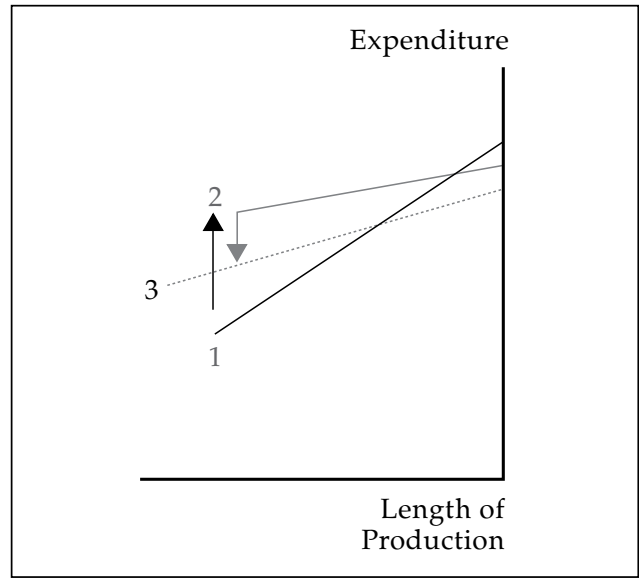

decisions are felt, they trigger in turn a different growth mechanism (without any new change of time preferences). The demand schedule for present goods and the level of investment rise while the interest rate rises again. ${ }^{6}$ The first growth mechanism tends to be superseded by a second. The initial change in relative spending is at least partially reversed while a saving based growth takes over. This is illustrated by the shift from line 2 to line 3 above. The structure of production is lengthened again and becomes thinner, which relative to the initial structure at $\mathrm{T}-1$ brings us back to the Rothbardian narrative as far as comparative statics is concerned (compare line 1 and 3 and see how similar it looks to the representation in diagram 1). The explanation of the process is different however, and hopefully more realistic here.

\footnotetext{
${ }^{6}$ We are assuming here that the changes in people's demand and supply schedules come as a surprise to each other. To the extent that they would be anticipated, schedules would include this speculative element and the volatility of the interest rate during the process would be lower.
} 


\section{VI \\ CONCLUSION}

The demand for present goods schedule on the time market and the volume of investment at any point in time tend to be inelastic to the interest rate and relatively insensitive to a shift of time preferences (compared to the supply for present goods schedule). They are essentially determined by the stock of productive factors in existence. They are therefore indirectly determined by past production decisions and valuations, mainly time preferences at various decisional points in past time and also preferences for labor over leisure during these past production processes. The demand schedule for present goods and the supply schedule of present goods determine the interest rate. As a consequence, the interest rate, the volume of investment and therefore the shape that the structure of production tends to have, are co-determined at any point in time directly by present time preference schedules and indirectly by past time preference schedules, and to a less important extent by past and present preferences for labor over leisure.

\section{BIBLIOGRAPHICAL REFERENCES}

HÜlsmanN, J.G. (2010): «The Structure of Production», Université d'Angers, Working Paper.

- (2008): «Time Preference and Investment Expenditure.» Procesos de Mercado, vol. V, n. $\mathrm{o}$ 2, pp. 313-333.

Rothbard, Murray N. (1993): Man, Economy, and State. ${ }^{\text {rdd }}$ ed., Auburn, Ala.: Mises Institute. 